\title{
The Interpretations of China's Exports-Productivity Paradox and Policy Implications
}

\author{
Pei-Zhi WANG ${ }^{1, a}$, Li-Ping SUN ${ }^{1, b, *}$, Shu-Yue ZHANG ${ }^{1, c}$ \\ ${ }^{1}$ School of International Economics and Trade, Shandong University of Finance and Economics, \\ Jinan,Shandong 250002,China \\ awpzmail@126.com, bunliping1999@126.com, ' zsy1994m@163.com
}

Keywords: Export-productivity paradox, Productivity heterogeneity, Foreign trade conditions heterogeneity, Foreign trade cost heterogeneity.

\begin{abstract}
Explaining China's Export-Productivity Paradox is a hot issue in the field of international trade. This paper attempts to systematically explain China's Export-Productivity Paradox from the perspective of trade driving force. The major factors affecting trade summarized by this paper are as follows: acquired endogenous comparative advantage(like high technical level),natural endogenous comparative advantage(like enterprise nature and orientation),acquired natural comparative advantage(like initial factor endowments) and acquired external comparative advantage(like better trade environment).The diversity of trade causes leads to various sources of heterogeneity. For developed countries, the foreign trade motivation derives from the acquired endogenous comparative advantage, and productivity difference always is the main heterogeneity source. For China, trade motivation comes from the remaining comparative advantage. Heterogeneity mainly including the foreign trade conditions heterogeneity and the foreign trade cost heterogeneity. In general, the paradox derives from the narrowness of heterogeneity and the particularities of China's trade.
\end{abstract}

\section{Introduction}

Nowadays, the extent of international division of labor has been deepening increasingly, and the multinational corporations have been booming prominently. Multinational enterprises have gradually become the principal players of international economic and trade activities. Studying on multinational corporations has been the frontier field of international trade theory. The principal study contents include the reasons for enterprises' internationalization ,the path choice for the internationalization of enterprises, and also enterprise endogenous border issues. Among these issues, the most hot and popular one is the study of path choice of internationalization of enterprises. According to heterogeneous firm theory, which has been successfully test basing on many developed countries data, only high-productivity firms will choose to export while low-productivity firms will focus exclusively on domestic markets[1].However, when perform empirical analysis based on China's firms data, many studies have come to the conclusion that low-productivity enterprises in China can still export their goods into international markets and high-productivity firms focus on domestic markets inversely. This special phenomenon has aroused the majority of scholars attempt to reveal the behind reasons.

Analyzing the reasons behind the paradox is extreme significant for theoretical development and practical guidance. Theory comes from practice, and theory needs to be tested in practice. We test a theory not for overthrowing it but for perfecting the theoretical model and improving its explanatory power and guiding effect on reality. Paradox is the challenge and development of the theory. The Export Productivity Paradox emerges in China showing that the current heterogeneous enterprise theory is still not fully applied to our country. Analysis the reasons behind the paradox is conducive to studying China's special trade status, finding out the real motivation of China's export trade, analyzing the persistence of this export model, and providing guidance for the internationalization of Chinese enterprises. 


\section{Definition of Export-Productivity Paradox}

Having a deep understanding on Heterogeneous firm theory is the basis of the Export Productivity Paradox research, and understanding the theory plays an important role in analyzing the existence and concepts of Export-Productivity Paradox.

The basic view of heterogeneous firm theory is that under the assumption that the cost of entering the international market is higher than the cost of entering the domestic market, enterprises choose international behavior according to their productivity, high-efficiency enterprises choose to export their products into international markets, low-efficiency enterprises choose focus on domestic markets, and the most lowest-efficiency enterprises have to exit market[2].

As this adverse empirical analysis result mainly based on China's enterprises data, so far there is no uniform definition of this phenomenon. So this article called this phenomenon as "China ExportProductivity Paradox". The Export-Productivity Paradox mainly includes two aspects: "Adverse self-selection effect" and "Crowding-out effect". The adverse self-selection effect means that low-efficiency enterprises voluntarily choose to export their products to international markets based on the edge of their own low-cost and favorable foreign trade environment. The crowding-out effect means that inefficient enterprises are forced to export due to their inability to survive in a fiercely competitive in domestic market.

\section{Interpretations of China's Exports-Productivity Paradox}

To explain the paradox is to search the reason why China's export firms' productivity is low and firms focus on domestic markets own high productivity. This article attempts to explain the paradox of export choice from the perspective of enterprise export motivation. The main reasons for the export are as followed: Acquired endogenous comparative advantage(like high technical level and high-productivity), Natural endogenous comparative advantage(like enterprises' nature and orientation), Acquired natural comparative advantage(like low cost and low price caused by initial factor endowments), Acquired external comparative advantage(like better trade environment, export promotion policies).

\section{From the Natural Endogenous Comparative Advantage Point of View}

The Natural endogenous comparative advantage comes from the nature of products as well as enterprises' nature and orientation.

If the enterprise chooses to export products with mature technology, the consumer demands are similar, so the natural endogenous comparative advantage is easily formed by produce and export labor-intensive products. Exporting mature technology products is much easier for enterprise as they do not need too much R \& D investment. These enterprises can directly construct factories to produce and export goods, so the enterprise will face a short payback period. The exported products are standardized production which satisfies general demands all over the world.

The second source is enterprises' nature and orientation. In the initial stage of general trade enterprises, the scale of the enterprises is small and can only focus on the domestic market; at the mature stage, with the increasing of $\mathrm{R} \& \mathrm{D}$ investment, technology accumulation and arising competitiveness of enterprises, the enterprise gradually expand the international market. But when it comes to processing trade enterprises, these enterprises only use the advantages of the country's initial factor endowments and trading conditions to avoid fierce domestic market competition. From the very beginning, they have targeted the manufacture of products with mature technology and exported them to the international market. Therefore, such enterprises do not prefer to invest in research and development but prefer production, do not prefer domestic markets but prefer exporting, this leads to the arising of export-productivity paradox[3]. 


\section{From the Perspective of Acquired Natural Comparative Advantage}

The Acquired natural comparative advantage comes from the low cost and low price caused by the initial factor endowments. Since 1978 Reform and Opening, the competitive advantage of China's foreign trade has basically followed the path of its initial comparative advantage, like abundant labor resources and mineral resources. As a result, most Chinese export enterprises located themselves as labor-intensive and resource-intensive ones, these enterprises attempt to export their products into the international market at lower prices, leading to the export firms with lower productivity.

\section{From the View of External Acquired Comparative Advantage}

Heterogeneous enterprise theory model does not take into consideration the existence of trade intermediaries. The theory is assumed that the export trade is direct trade, which means a country's exporter directly sell their products to consumers in another country. In reality, many enterprises export their products through trade intermediaries. Trade intermediaries have a wealth of export experience and trade channels. Enterprises with lower-productivity cannot afford high direct export costs. The existence of export intermediaries reduces the export costs of inefficient enterprises, and a large number of low-efficiency enterprises have realized exports. So the existence of trading intermediaries leading to paradox.[4]

When it comes to the continuously optimizing trading environment, Our government has long implemented an export-oriented policy that directly or indirectly encourages exporters to export such as enforcing export tax rebates and subsidies. At the same time, China actively negotiates with other countries in order to reach multilateral or bilateral economic and trade agreements in order to optimize the environment for foreign trade markets, such as actively promoting the construction of High-lever bilateral FTAs network. These export-oriented policies and the optimization of foreign trade environment policies reduce the marginal cost threshold for export of enterprises, leading lower-productivity enterprises also have access to international markets and causing appearance of paradoxes. Moreover, the more effective the trade promoting policies will be, the more obvious effect the export-productivity paradox will engender .

Ju-Lan DU (2012) [5]found that export-oriented processing enterprises generally had the export trade experience in the past and stable sales channels in foreign markets. The cost of entering overseas markets was lower than the cost of entering the domestic market. Therefore, exports became the spontaneous choice of low-productivity enterprises. That is to say, the self-choice effect depends not only on firm productivity but also on firm orientation and firm export costs.

\section{Policy Implications for China's Economy and Trade Transformation}

Take mechanisms to improve the quality of workforce and the quality of the population, which allows job-seekers to actively seek high-quality jobs and qualified high-quality jobs. At the same time, it is conducive to improving the overall quality of our labor force, enhancing our innovation ability , nurturing and accumulating human capital and improving long-term productivity.

To step by step to limit and eliminate some sunset industries, such as High energy consumption and high pollution enterprises. We should become more purposeful and active in pursuing green, economical, innovative and efficient development. The government should give incitements and support to enterprises which interested in increasing $\mathrm{R} \& \mathrm{D}$ investment and aiming at improving product added value[6]. At the same time, we must encourage innovation, strengthen the protection of intellectual property and optimize the environment for innovation. In these ways, competitiveness gained by technological innovation can be sustained for a long period.

The government should moderately adjust its foreign trade policies and measures, adopt different trade policies toward different types of enterprises. Policies should be lean towards high-productivity enterprises in order to encourage enterprise to export high-tech and high value-added products. [7] Do not look for markets for outdated firms,but encourage and guide 
inefficient enterprises to shut down or upgrading their manufacturing technology or go abroad to set up factories.

Actually, implementing direct export tax rebates and export subsidies and other direct control policies will increase export enterprises dependence and innovation inertia, the policy should be changed to improve the export environment (such as the construction of FTAs, timely release of international market information, etc.), reduce export costs (rapid customs clearance, etc.),and also reduce export risk (vigorously export insurance, etc.) .

Be more cautious about foreign investment. Foreign investment should pay more attention to driving local enterprises' technological progress and improve innovation capability. Government should encourage foreign-funded enterprises to invest in high-tech products and industries at the micro level.

\section{Summary}

The existence of China's Export Productivity Paradox shows that the model of China's export trade is different from developed countries' trade models. For developed countries, the foreign trade motivation derives from the acquired endogenous comparative advantage, and productivity difference always is the main heterogeneity source. For China, trade motivation comes from the remaining comparative advantage including natural endogenous comparative advantage, acquired natural comparative advantage and acquired external comparative advantage. These factors are non-productivity factors which will not provide core competitiveness for China's enterprises. To survive in the intense trade competition between countries, feasible strategies need to be employed to accumulation of human capital, enhance the innovation capacities, foster long-term comparative advantages and promote the transformation and upgrading of China's economics and trade.

\section{References}

[1] Marc Melitz, The Impact of Trade on Intra-industry Reallocations and Aggregate Industry Productivity, J. Econometrica, 71(2003)1695-1725.

[2]Marc Melitz, Bilbiie FO, Ghironi F. Endogenous Entry, Product Variety, and Business Cycles, J. Journal of Political Economy, 120(2012) 304-345.

[3]Chun-Ding LI, Xiang-Shuo YIN, Chinese Export Firms'، Productivity Paradoxanits Explanations ,J. Finance\& Trade Economics,11(2009)85-89. (In Chinese)

[4] Chun-Ding LI, Ding-Xiang TANG,Export and Firm Productivity: Chinese Data Test Based on New-new Trade Theory, J. Journal of International Trade, 9(2010)13-19. (In Chinese)

[5] Ju-Lan DU, Yi LU, Zhi-Gang TAO, Lin-Hui YU, Do Domestic and Foreign Exporters Differ in Learning by Exporting? Evidence from China, J. China Economic Review,23(2012) 296-315.

[6]Mallick S, Yank Y, Export Premium, Self-selection and Learning-by-exporting: Evidence from Matched Chinese Firms, J. The World Economy,33 (2010):1218-1240.

[7] Lei XU ,Xiang-ShuoYIN, Analysis on Chinese Export Firms'"Productivity Paradox" from the Perspective of Trade Cost, J.International Business, 3(2012):13-26(In Chinese) 